\title{
KESESUAIAN PROGRAM PENGELOLAAN DALAM MENGATASI PERMASALAHAN AIR PERKOTAAN DI KOTA SURAKARTA
}

\author{
Jayanti Kusuma Wardhani, Paramita Rahayu, Erma Fitria Rini \\ Prodi Perencanaan Wilayah dan Kota, Fakultas Teknik, Universitas Sebelas Maret \\ Jl. Ir. Sutami 36A, Surakarta \\ e-mail: jaywardha@gmail.com
}

\begin{abstract}
ABSTRAK
Air perkotaan sangat penting dalam menunjang aktivitas masyarakat perkotaan. Keberadaan airperkotaan semakin langka dikarenakan semakin tingginya pertambahan penduduk yang menyebabkan kebutuhan akan air juga meningkat serta aktivitas perkotaan yang semakin intensif. Permasalahan-permasalahan mengenai air perkotaan terjadi hampir di seluruh kota yang ada di Indonesia, tak terkecuali terjadi juga di Kota Surakarta. Oleh karena itu untuk mengatasi permasalahan-permasalahan tersebut, diperlukan kesesuaian program pengelolaan air perkotaan dalam mengatasi permasalahan-permasalahan air perkotaan di Kota Surakarta. Berdasarkan hasil analisis triangulasi sumber data yang telah dilakukan dapat diketahui bahwa program yang dilakukan telah mengarah pada penyelesaian permasalahan air perkotaan yang ada di Kota Surakarta. Tetapi tidak semua permasalahan air perkotaan tersebut dapat teratasi. Terdapat permasalahan air perkotaan yang saat ini masih belum teratasi yaitu mengenai hal kelangkaan air, karena belum adanya program yang dibuat. Selain itu terdapat pula permasalahan yang masih jauh dalam penyelesaiannya karena terkendala dalam hal pendanaan. Program yang dibuat dirasa sudah cukup mampu sedikit demi sedikit untuk menanggulangi permasalahan air perkotaan yang ada, ini dibuktikan dengan program yang dilakukan secara terus menerus dan berkelanjutan serta adanya pengecekan dan monitoring dan telah melibatkan seluruh stakeholder.
\end{abstract}

Kata Kunci : Air Perkotaan, Kesesuaian Program, Pengelolaan Sumber Daya Air Terpadu, Permasalahan Air Perkotaan, Tata Kelola Air Perkotaan.

\begin{abstract}
Urban water is essential to support the urban community activities. The existence of urban water is more scarce because of the increasing of growth population cause the increasing needs of urban water and the urban activities which more intensive. The problems of urban water occurs in most of the cities in Indonesia, and this problem also happens in Surakarta. Therefore, to resolve that problems, the suitability of urban water management program to resolve urban water problems in Surakarta is neede. Based on the result of triangulation analysis of data sources that has been done, it can be seen that the program carried out has led to resolve the urban water problems in Surakarta. But not all of them can be resolved. There is the problem of urban water can't resolved yet about water scarcity, because there's no program created yet. In addition there are also problems that are still far from being resolved due to constraints in funding. Program which made are felt enough gradually to ward off the urban water problems, it can be proved by the program that done continuously and sustainable also there are checking and monitoring and has involved all of the stakeholders.
\end{abstract}

Keywords: Urban Water, Program Suitability, Intergrated Water Resources Management, Urban Water Problems, Urban Water Governance.

\section{PENDAHULUAN}

Urbanisasi merupakan salah satu faktor yang mempengaruhi ketersediaan air perkotaan. Dalam proses urbanisasi ditandai dengan migrasi secara besar-besaran dari pedesaan menuju perkotaan sehingga menyebabkan ledakan penduduk secara tiba-tiba. Hal ini ditandai dengan semakin intensifnya aktivitas masyarakat yang terjadi di perkotaan. Kenaikan populasi yang terjadi di perkotaan ternyata menimbulkan banyak masalah yang salah satunya adalah pencemaran dan kelangkaan air perkotaan yang sering menjadi masalah utama pada kota-kota di Indonesia, tak terkecuali terjadi juga di Kota Surakarta.

Dalam pemenuhan kebutuhan air, Kota Surakarta memanfaatkan air tanah dan air permukaan. Untuk air tanah yang ada di Kota Surakarta sudah tidak dapat lagi dimanfaatkan sebagai sumber air bersih, karena kualitas air tanah yang ada di Kota Surakarta sudah buruk dan telah tercemar oleh berbagai macam limbah khususnya limbah industri dan domestik. Kemudian untuk air permukaan yaitu sungai berdasarkan laporan yang dikeluarkan oleh Direktorat Jenderal Pengendalian Pencemaran dan Kerusakan Lingkungan Kementerian Lingkungan 
Hidup dan Kehutanan (KLHK), di tahun 2015 hampir 68 persen atau mayoritas mutu air sungai di 33 provinsi di Indonesia dalam status tercemar berat. Tak terkecuali sungai-sungai yang ada di Kota Surakarta. Kondisi sungai-sungai yang ada Surakarta dapat dikatakan memprihatikan. Ini dikarenakan hampir seluruh sungai yang ada di Kota Surakarta sudah tercemar, yang kebanyakan disebabkan oleh hasil dari limbahlimbah industri.

Sehingga diperlukan program-program atau usaha dalam menanggulangi permasalahan air perkotaan. Untuk mengatasi permasalahanpermasalahan tersebut, diperlukan kesesuaian antara program pengelolaan air perkotaan dengan permasalahan-permasalahan air perkotaan yang ada di Kota Surakarta. Dibutuhkan identifikasi permasalahan air perkotaan dan juga stakeholderstakeholder yang terlibat serta program-program pengelolaan air perkotaan di Kota Surakarta. Oleh karena itu penelitan ini diperlukan untuk mengetahui kesesuaian program dan lesson learned dari masing-masing stakeholder dalam hal pengelolaan air perkotaan dalam mengatasi permasalahan air perkotaan di Kota Surakarta.

\section{TINJAUAN PUSTAKA}

\section{Air Perkotaan}

Pengertian Sumber Daya Air (SDA) menurut PP No.121 Tahun 2015 tentang Pengusahaan Sumber Daya Air, sumber daya air adalah air, sumber air, dan daya air yang terkandung di dalamnya, adalah semua air yang ada di atas ataupun di bawah permukaan tanah.Sumber daya air didukung oleh infrastruktur kelompok air yang mencakup air perkotaan. Air perkotaan didefinisikan sebagai air yang digunakan oleh masyarakat dalam menunjang kebutuhan atau aktivitas sehari-hari sehari-hari seperti kegiatan rumah tangga, pertanian, industri, dan lain-lain. Sehingga dapat disimpulkan bahwa salah satu komponen dari sumber daya air adalah air perkotaan. Air perkotaan terdiri dari air bersih dan air limbah.

\section{Permasalahan Air Perkotaan}

Semakin meningkatnya pertumbuhan penduduk yang ada di perkotaan mengakibatkan kebutuhan akan air perkotaan semakin tinggi sedangkan ketersediaan air perkotaan tidak mengalami peningkatan dalam hal kuantitasnya. Sehingaa muncul permasalahan-permasalahan yang berkaitan dengan air perkotaan. Berdasarkan teori dari beberapa ahli didapakan sintesis permasalahan air perkotaan yaitu kelangkaan air (Stef Koop, 2015), banjir (Stef Koop, 2015), pencemaran air (Stef Koop, 2015), perubahan iklim (EEA 2012; UCCRN, 2011).

\section{Pengelolaan Sumber Daya Air (Water Management)}

Pengelolaan sumber daya air sangat dibutuhkan untuk keberlanjutan keberadaan sumber daya air. Ini dikarenakan kebutuhan air yang semakin meningkat sehingga diperlukan pengelolaan agar kebutuhan air dapat terpenuhi. Pengelolaan sumber daya air adalah upaya merencanakan, melaksanakan, memantau, dan mengevaluasi penyelenggaraan konservasi sumber daya air, dan pengendalian daya rusak air. Dari beberapa teori terkait, didapatkan sintesis pengelolaan sumber daya air, di antaranya adalah pemanfaatan sumberdaya air (Sudanti dan Budiharjo, 2000; Jacobus Samidjo, 2014), pelestarian sumber daya air (Jacobus Samidjo, 2014), dan pengelolaan air terpadu (Sudanti dan Budiharjo, 2000).

\section{Pengelolaan Sumber Daya Air Terpadu (Integrated Water Resources Management)}

Dalam mewujudkan keberlangsungan sumber daya air maka muncul konsep pengelolaan sumber daya air terpadu (Integrated Water Resources Management). IWRM adalah sebuah konsep yang mempromosikan koodinasi pengembangan dan pengelolaan air, tanah, dan sumber-sumber terkait dengan tujuan untuk mengoptimalkan fungsi ekonomis dan kesejahteraan sosial dalam perilaku yang sesuai tanpa mengganggu kestabilan ekosistemekosistem penting (Kodoatie \& Sjarief, 2005). IWRM ini merupakan sebuah solusi untuk mengatasi permasalahan-permasalahan terkait dengan air perkotaan. Dari berbagai sumber, dapat diidentifikasi prinsip pengelolaan sumber daya air terpadu (Integrated Water Resources Management) adalah kebijakan atau program yang menyeluruh (UNDP, 2006), kolaborasi atau keterlibatan stakeholder (Wong et al, 1999 dalam Norken, 2003), pemerataan dan pemanfaatan air (Wong et al, 1999 dalam Norken, 2003), peningkatan kualitas air (Wong et al, 1999 dalam Norken, 2003).

\section{Kolaborasi Stakeholder}

Kolaborasi digunakan dalam kegiatan kerja sama atau kemitraan yang melibatkan berbagai pihak untuk mencapai tujuan yang sama. Tujuan 
utama dalam dilakukannya kolaborasi adalah untuk menyatukan persepsi atau pikiran dari berbagai pihak untuk mendapatkan hasil-hasil yang diinginkan. Pengertian kolaborasi adalah interaksi dengan sharing pengetahuan untuk menemukan solusi bersama (Gray, 1989; Kamus Heritage Amerika, 2000; Jonathan, 2004; Lindeke; Sieckert, 2005).

Stakeholder dalam pengelolaan air perkotaan merupakan individu maupun organisasi yang terlibat dan memiliki pengaruh dalam suatu kegiatan pengelolaan air perkotaan untuk mencapai tujuan tertentu. Menurut Reed et al (2009) terdapat beberapa klasifikasi stakeholder dalam pengelolaan air perkotaan, yaitu dengan kriteria:

- Stakeholder subyek, adalah stakeholder yang mempunyai tingkat kepentingan tinggi dan pengaruh yang rendah.

- Stakeholder key player, merupakan stakeholder yang memiliki tingkat kepentingan tinggi dan pengaruh yang tinggi.

- Stakeholder context setter, adalah stakeholder yang mempunyai tingkat kepentingan rendah dan pengaruh yang tinggi.

- Stakeholder crowd, merupakan stakeholder yang memiliki tingkat kepentingan rendah dan pengaruh yang rendah.

Variabel dalam penelitian ini didapatkan dari sintesis permasalahan air perkotaan, ini dikarenakan dalam penelitian ini ingin mengevaluasi tata kelola air perkotaan dengan cara menilai kesesuaian program dalam mengatasi permasalahan air perkotaan. Sedangkan untuk sub variabel adalah sintesis dari teori pengelolaan sumber daya air terpadu. Berdasarkan uraian di atas didapatkan variabel penelitian sebagai berikut.

Tabel 1. Variabel dan sub Variabel Penelitian

\begin{tabular}{|c|c|}
\hline $\begin{array}{l}\text { Variabel } \\
\text { Penelitian }\end{array}$ & Sub Variabel Penelitian \\
\hline \multirow{4}{*}{ Kelangkaan air } & Kebijakan atau program yang menyeluruh \\
\hline & Kolaborasi atau keterlibatan stakeholder \\
\hline & Pemerataan dan pemanfaatan air \\
\hline & Peningkatan kualitas air \\
\hline \multirow{2}{*}{ Banjir } & Kebijakan atau program yang menyeluruh \\
\hline & Kolaborasi atau keterlibatan stakeholder \\
\hline \multirow{4}{*}{ Pencemaran air } & Kebijakan atau program yang menyeluruh \\
\hline & Kolaborasi atau keterlibatan stakeholder \\
\hline & Pemerataan dan pemanfaatan air \\
\hline & Peningkatan kualitas air \\
\hline \multirow{2}{*}{ Perubahan iklim } & Kebijakan atau program yang menyeluruh \\
\hline & Kolaborasi atau keterlibatan stakeholder \\
\hline
\end{tabular}

\section{METODE PENELITIAN}

Pendekatan yang digunakan pada penelitian ini menggunakan pendekatan studi kasus dengan jenis penelitian kualitatif. Proses pengumpulan data dilakukan dengan melakukan survei primer berupa wawancara dan juga survei sekunder berupa studi literature yang dilakukan pada instansi yang terlibat langsung yang ditentukan dengan menggunakan analisis stakeholder menurut (Reed et al, 2009) terdapat dalam hal pengelolaan air perkotaan seperti Bappeda, PDAM, DLH, DPU, BPBD, dan BBWS. Wawancara yang dilakukan adalah wawancara secara terstruktur dan terbuka untuk mengetahui permasalahan air perkotaan dan juga lesson learned serta terkait prinsip IWRM dari pelaksanaan program pengelolaan air perkotaan. Data tersebut kemudian dianalisis dengan teknik analisis deskriptif kualitatif dan triangulasi sumber data. Kerangka analisis pada penelitian ini adalah sebagai berikut.

\section{Input}

- Permasalahan Air Perkotaan

- Program pengelolaan untuk mengatasi permasalahan air perkotaan dan lesson learned dari pelaksanaan program

- Prinsip IWRM

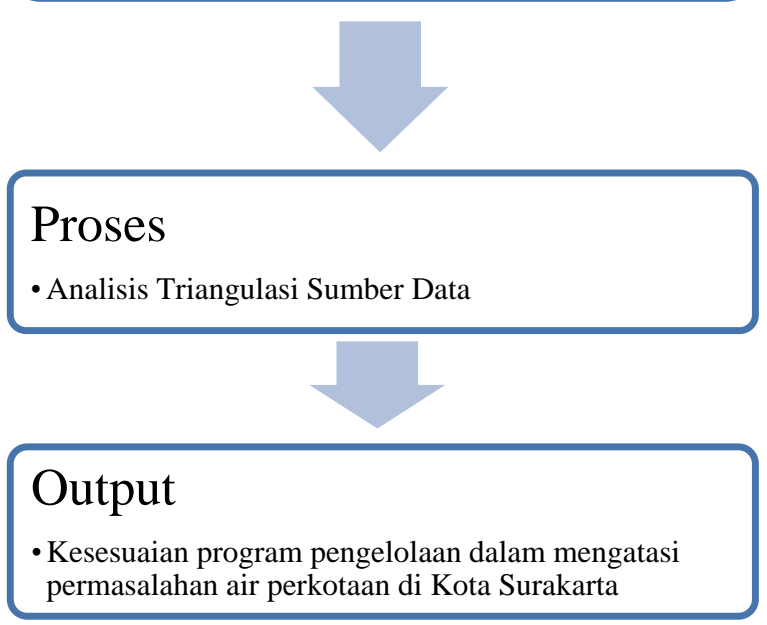

Gambar 1. Kerangka Analisis Penelitian

\section{HASIL DAN PEMBAHASAN}

\section{Gambaran Umum Air Perkotaan di Kota Surakarta}

Untuk memenuhi kebutuhan air bersih perkotaan yang ada di Kota Surakarta, pemerintah Kota Surakarta (PDAM Kota Surakarta) mengatasinya dengan menggunakan mata air Cokrotulung. Daerah pelayanan PDAM Kota Surakarta pada dibagi menjadi 4 kawasan pelayanan, yaitu: 
1) Kawasan Utara, meliputi sebagian Kecamatan Banjarsari, sebagian Kecamatan Jebres dan Plesungan Kecamatan Gondangrejo (Kabupaten Karanganyar).

2) Kawasan Timur, meliputi sebagian Kecamatan Jebres.

3) Kawasan Barat, meliputi sebagian Kecamatan Banjarsari, sebagian Kecamatan Jebres, sebagian Kecamatan Laweyan, sebagian Kecamatan Pasar Kliwon, Kecamatan Delanggu, sebagian Kecamatan
Kartasura, Kecamatan Banyudono (Desa Sambon), dan sebagian Kecamatan Sawit.

4) Kawasan Selatan, meliputi sebagian Kecamatan Laweyan, sebagian Kecamatan Pasar Kliwon, sebagian Kecamatan Serengan, Daerah perbatasan Kabupaten Sukoharjo, sebagian Kecamatan Kartasura.

Berikut ini adalah peta pembagian area pelayanan PDAM Kota Surakarta.

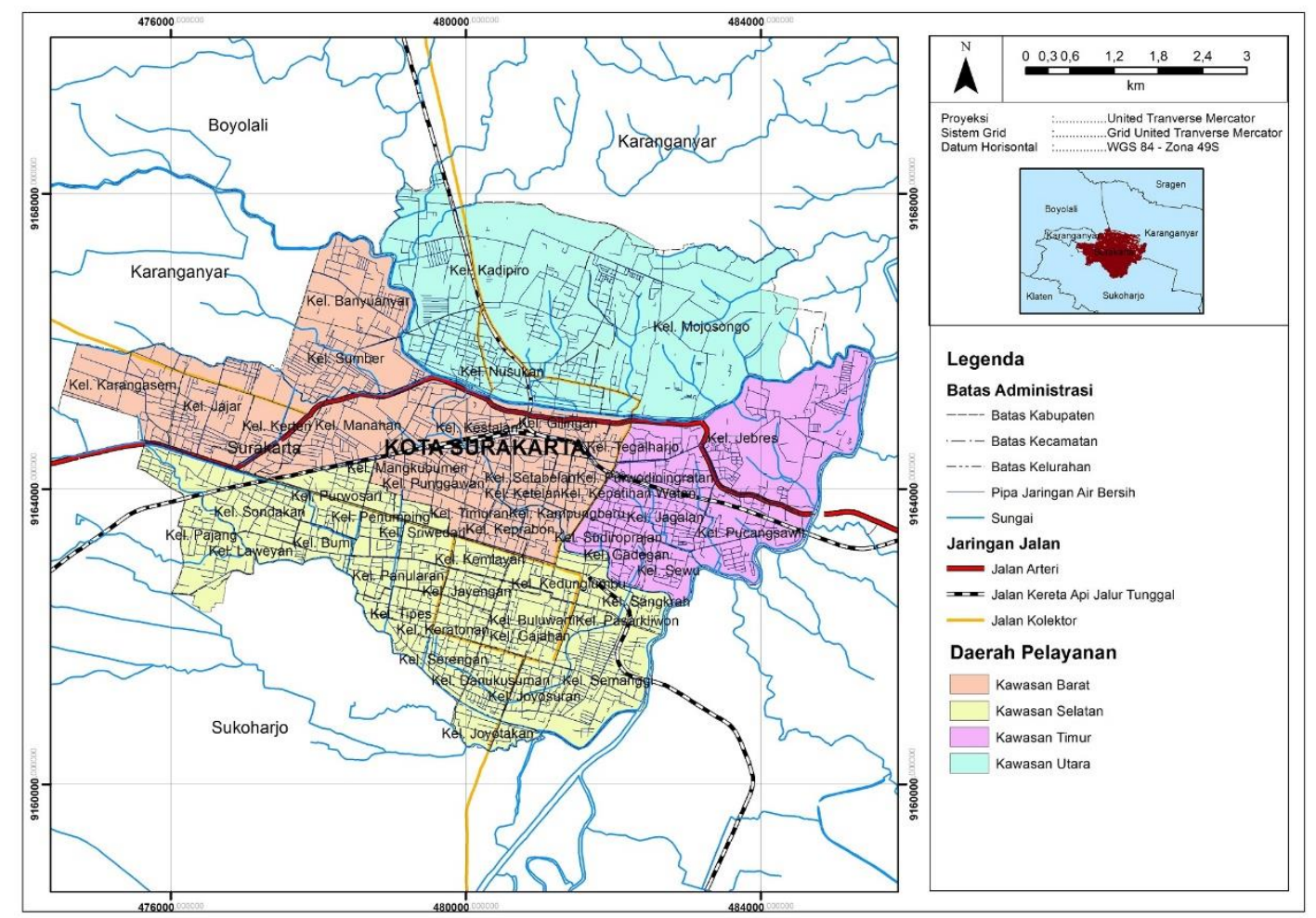

Gambar 2. Peta Pembagian Area Pelayanan PDAM Kota Surakarta

(Peta RBI Bakosurtanal, 2012; Peta Administrasi RTRW Kota Surakarta 2011-2031; PDAM, 2018)

Sedangkan untuk masyarakat yang tidak berlangganan dari PDAM menggunakan sumber air dari sumur dalam yang dikelola oleh kelompok swadaya masyarakat (KSM) di bawah pembinaan dan pengawasan Dinas Pekerjaan Umum Kota Surakarta Bidang Cipta Karya. Beberapa daerah yang menggunakan sumber air dari sumur dalam adalah sebagian Kelurahan Kadipiro, Mojosongo, Jebres, Sewu, Tipes. Berikut ini adalah peta persebaran sumur dalam di Kota Surakarta. 


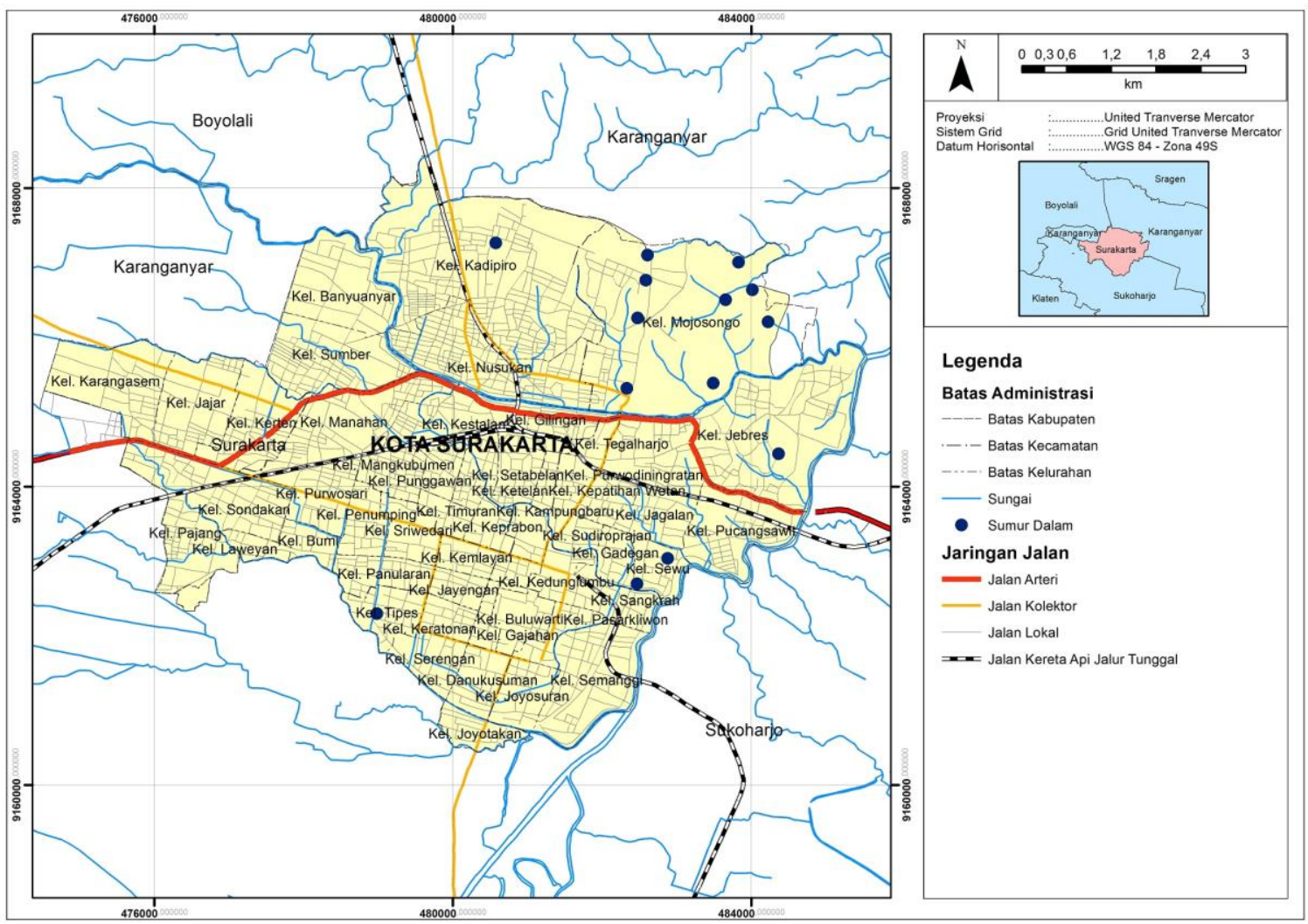

Gambar 3. Peta Persebaran Sumur Dalam Kota Surakarta

(Peta RBI Bakosurtanal, 2012; Peta Administrasi RTRW Kota Surakarta 2011-2031; PDAM, 2018)

\section{Identifikasi Permasalahan Air Pekotaan di Kota Surakarta}

\section{1) Kelangkaan Air}

Berdasarkan data wawancara dan data sekunder memberikan informasi beberapa permasalahan terkait kelangkaan air yang ada di Kota Surakarta antara lain sebagai berikut;

a. Adanya kehilangan atau kebocoran air (RISPAM Kota Surakarta, 2016)

Dalam pendistribusian air bersih ke masyarakat, pihak PDAM Tirta Dharma Kota Surakarta menemukan adanya tingkat kehilangan air/kebocoran air baik volume yang diproduksi maupun yang terdistribusi. Untuk tingkat kebocoran air saat ini mencapai $39,26 \%$.

b. Kualitas air tanah dan sumur dalam kurang baik. (Wawancara PDAM, 2018)

"Untuk masyarakat yang tidak berlangganan PDAM atau yang menggunakan air tanah ataupun sumur dalam untuk kualitas airnya tidak terlalu bagus"

c. Pipa jaringan PDAM kondisinya sudah tidak layak (Wawancara PDAM, 2018)

"Pipa-pipa jaringan yang digunakan oleh PDAM dalam mendistribusikan air untuk kondisinya sudah tidak layak dan sudah berkarat. Hal inidikarenakan usia pipa yang sudah tua, sehingga terkadang terjadi penyumbatan dan kemudian air yang keluar debitnya kecil"

d. Belum tercapainya kontinuitas air (RISPAM Kota Surakarta, 2016)

Kontinuitas air yang terdistribusikan untuk masyarakat hanya berkisar 21,49 jam per hari atau belum 24 jam. Hal ini disebabkan adanya kekurangan reservoir dan pemerataan tekanan air yang masih kurang.

e. Semakin menurunnya debit produksi pada sumur dalam (RISPAM Kota Surakarta, 2016)

Keberadaan sumur dalam yang semula ada 28 sumur dalam saat ini tinggal 22 sumur dalam aktif. Ini mengakibatkan masyarakat yang semula terlayani air dengan sumur dalam menjadi tidak terlayani yang kemudian masyarakat pada kawasan tersebut mengalami masalah kelangkaan air.

f. Tidak adanya sumber air lain. (RISPAM Kota Surakarta, 2016)

Dengan semakin berkurangnya ketersediaan air yang ada di Kota Surakarta mengakibatkan diperlukannya usaha dalam menanggulangi permasalahan tersebut yaitu dengan memanfaatkan air dari sumber lain yaitu Sungai Bengawan Solo. Tetapi dapat diketabui bahwa air yang ada di Sungai Bengawan Solo telah mengalami 
pencemaran sehingga diperlukan pengolahan terlebih dahulu agar air dari Sungai Bengawan Solo layak untuk digunakan, selain itu dalam pengolahannya ternyata membutuhkan biaya tinggi.

Berdasarkan permasalahan-permasalahan tersebut dapat diketahui bahwa terdapat berbagai macam masalah dalam hal kelangkaan air. Menurut Ibu Upik (PDAM), untuk masalah kelangkaan air di Kota Surakarta adalah lebih utamanya pada hal mengenai kebocoran air, ini sesuai yang diungkapkan beliau;

"Kelangkaan air di Kota Surakarta itu lebih dikarenakan masih tingginya tingkat kebocoran air. PDAM sampai saat ini masih belum bisa mengatasinya dikarenakan kebocoran air ini terjadi saat proses pendistribusiannya pada pelanggan sehingga PDAM itu ya masih sulit untuk mendeteksinya"

Sehingga berdasarkan hasil wawancara maupun dari data dokumen yang telah diperoleh dapat disimpulkan bahwa terdapat beberapa masalah-masalah dalam hal kelangkaan air yang dialami Kota Surakarta sehingga diperlukan usaha-usaha ataupun program-program agar permasalahan mengenai hal kelangkaan air tersebut dapat segera teratasi.

\section{2) Banjir}

Berdasarkan data wawancara dan data sekunder memberikan informasi beberapa permasalahan terkait banjir dan genangan yang ada di Kota Surakarta antaralain sebagai berikut;

a. Permasalahan drainase (Wawancara DPU, 2018)

"Terdapat beberapa titik drainase di Kota Surakarta yang bermasalah. Selain itu juga adanya sedimentasi ini dikarenakan saluran yang ada merupakan saluran peninggalan Belanda yang usianya sudah tua dan tidak layak sehingga diperlukan pemeliharaan"

b. Penutupan dan pendirian bangunan di atas drainase (Wawancara DPU, 2018)

"Banyak masyarakat Kota Surakarta mendirikan bangunan baik permanen maupun non permanen di atas drainase, hal ini menyebabkan drainase menjadi tertutup dan air tidak dapat mengalir secara maksimal"

c. Terdapat beberapa titik lokasi yang masih belum mempunyai tanggul (Wawancara BBWS, 2018)

"Ada beberapa lokasi badan air di Kota Surakarta yang belum memiliki tanggul, sedangkan untuk tanggul yang ada di Sungai
Bengawan Solo tidak mampu menahan air saat intensitas curah hujan tinggi"

d. Kurangnya kesadaran masyarakat terhadap lingkungan (Wawancara DPU, 2018)

"Kurangnya kesadaran masyarakat ini dibuktikan denganmasih banyaknya masyarakat Kota Surakarta yang membuang sampah sembarangan di sungai"

Berdasarkan permasalahan-permasalahan mengenai banjir di atas dapat disimpulkan bahwa penyebab dari permasalahan banjir di Kota Surakarta adalah rendahnya kualitas sarana prasarana untuk mencegah terjadinya banjir, seperti adanya sedimentasi, buruknya drainase, serta masih belum danya tanggul pada beberapa titik. Selain itu, kurangnya kesadaran masyarakat juga menjadi salah satu permasalahan dalam hal banjir, ini dibuktikan dengan masih adanya yang membuang sampah di sungai. Berikut ini adalah peta kawasan banjir dan genangan di Kota Surakarta.

\section{3) Pencemaran Air}

Berdasarkan hasil dari wawancara dan data sekunder, ditemukan permasalahan-permasalahan yang terjadi terkait dengan hal pencemaran air yang ada di Kota Surakarta, antara lain;

a. Penanganan limbah industri belum terkelola (Wawancara DLH, 2018)

"Limbah cair dari sektor indutri, khususnya industri rumah tangga banyak yang langsung dibuang ke sungai tanpa melalui proses pengolahan terlebih dahulu."

b. Perilaku dan pengetahuan masyarakat untuk tidak membuang limbah domestik ke sembarang tempat masih sangat rendah (Wawancara DLH, 2018)

"Kurangnya kesadaran masyarakat tentang pentingnya menjaga lingkungan sehingga banyak masyarakat masih membuang limbah domestik ke sungai."

c. Belum maksimalnya monitoring sarana komunal terbangun di Kota Surakarta (Masterplan Air Limbah Domestik, 2016)

Sebanyak 38 IPAL komunal dan MCK komunal di Kota Surakarta belum teridentifikasi kualitas limbahnya, belum pernah ada monitoring kualitas air buangan di sarana komunal terbangun, dan belum pernah ada penyedotan berkala di semua sarana terbangun.

d. Rendahnya pemasangan pipa atau saluran air limbah (Masterplan Air Limbah Domestik, 2016)

Kurangnya kesadaran masyarakat untuk menyambungkan pipa buangan limbah 
domestik melalui sambungan rumah PDAM menjadi isu utama. Saat ini hanya $14,83 \%$ warga yang memakai sistem off site (perpipaan) di Kota surakarta.

e. IPLT yang tidak berfungsi (Masterplan Air Limbah Domestik, 2016)

IPLT Putri Cempo merupakan infrastruktur milik PDAM yang berfungsi untuk mengolah buangan limbah tinja di wilayah Kota Surakarta.IPLT tersebut juga berfungsi sebagai pusat pembuangan air limbah dari layanan sanitasi individu bagi warga yang belum terjangkau akses IPAL komunal. Akses jalan menuju IPLT tidak bisa ditempuh karena terhalang timbunan sampah TPA dari kurun waktu 2007 - 2013.

f. Kurang optimalnya kapasitas kelembagaan pengelolaan air limbah. (Masterplan Air Limbah Domestik, 2016)
Kurang optimalnya kapasitas kelembagaan pengelolaan air limbah disebabkan terbatasnya kapasitas jumlah SDM.

g. Minimnya pendanaan APBD (Masterplan Air Limbah, 2016)

Minimnya pendanaan APBD untuk alokasi penanganan limbah di Kota Surakarta masih tergolong rendah sehingga menyebabkan pencapaian SR belum maksimal.

h. Pelanggaran dalam hal lingkungan hidup (Masterplan Air Limbah, 2016)

Pelanggaran yang dilakukan khususnya mengenai prosedur penanganan air limbah masih kurang, sehingga masyarakat dan sektor swasta terkesan tidak mengindahkan larangan dan peraturan yang telah ditetapkan.

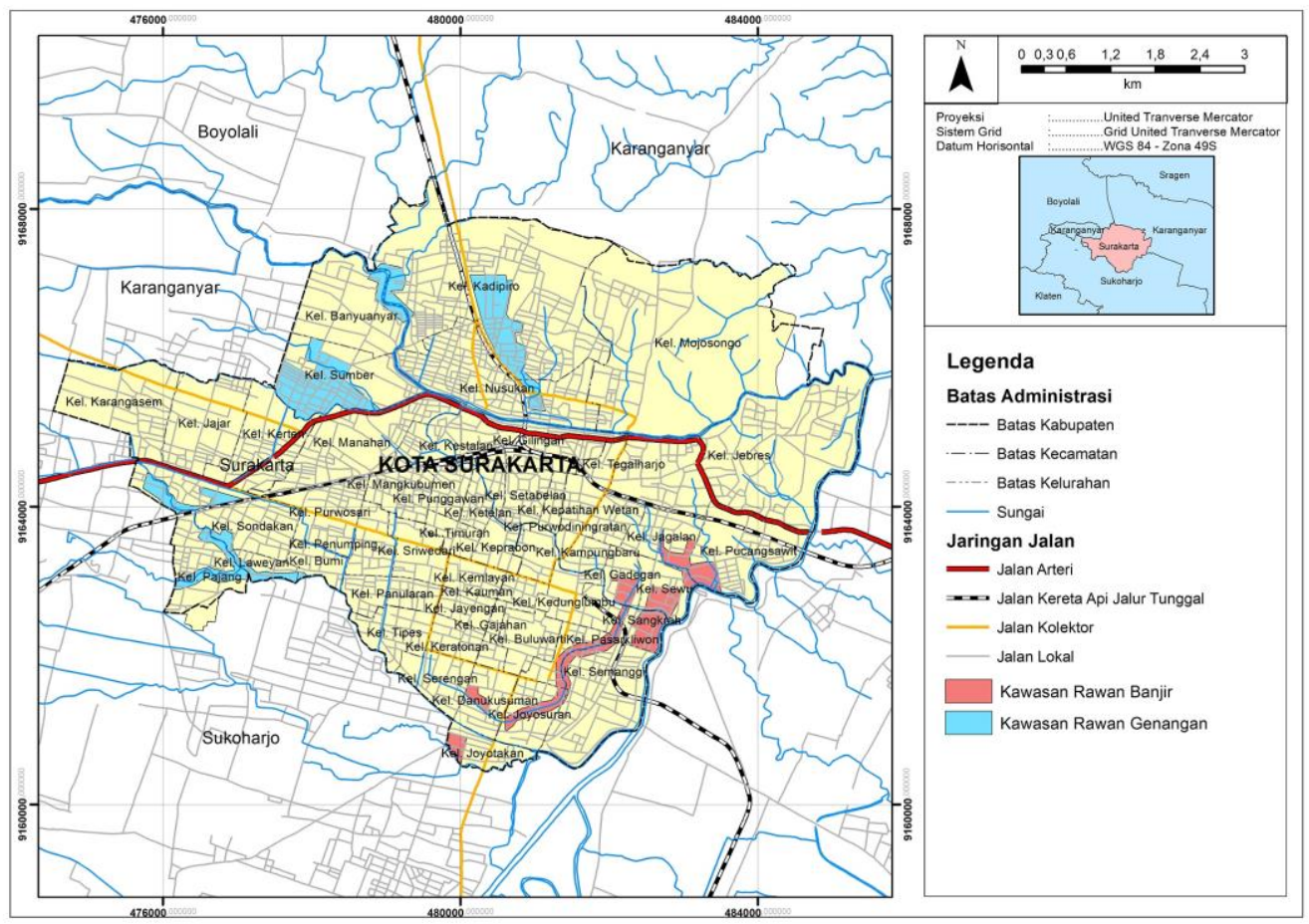

Gambar 4. Peta Kawasan Rawan Banjir dan Genangan Kota Surakarta (Peta RBI Bakosurtanal, 2012; Peta Administrasi RTRW Kota Surakarta 2011-2031; DPU, 2018)

Sehingga berdasarkan hasil wawancara dan hasil studi dokumen yang telah dilakukan dapat disimpulkan bahwa pencemaran air yang terjadi di Kota Surakarta utamanya dikarenakan masalah pembuangan limbah sembarangan di badan air atau sungai khususnya yang paling banyak adalah limbah industri rumahan atau home industry dan juga limbah rumah tangga, tanpa adanya proses pengolahan limbah terlebih dahulu. Ini mengakibatkan tingkat pencemaran air yang ada di Kota Surakarta semakin memburuk, sehingga air yang ada di Kota Surakarta tidak layak untuk digunakan atau dikonsumsi serta perilaku dan pengetahuan masyarakat untuk tidak membuang limbah domestik ke sembarang tempat masih sangat rendah.

\section{4) Perubahan Iklim}

Berdasarkan hasil wawancara dan studi dokumen yang telah dilakukan untuk Permasalahan yang terjadi terkait dengan hal perubahan iklim di Kota Surakarta adalah terjadinya kerusakan-kerusakan lingkungan (Wawancara DLH, 2018). Kerusakan lingkungan yang terjadi adalah seperti erosi dan sedimentasi 
pada drainase yang ada di Kota Surakarta. Selain itu banyaknya polusi udara akibat dari asap kendaraan besar yang menyebabkan kualitas udara menjadi buruk. Semakin minimnya vegetasi maupun catchment area yang ada di Kota Surakarta juga menyebabkan air hujan tidak dapat terserap sehingga supply air semakin berkurang. Kemudian tidak adanya pemilahan dan pengelolaan sampah, sehingga sampah yang ada dibakar dan gas yang dihasilkan memperparah terjadinya perubahan iklim.

\section{Identifikasi Program Pengelolaan dalam Mengatasi Permasalahan Air Perkotaan}

\section{a) Program Pengelolaan dalam Mengatasi Kelangkaan Air}

Berdasarkan studi literatur yang telah didapatkan, telah ada beberapa program yang dilakukan untuk menanggulangi permasalahan kelangkaan air yang ada di Kota Surakarta. Terdapat beberapa program yang telah dilaksanakan dan saat ini masih berlangsung serta terdapat pula program yang masih menjadi rencana yang akan dilakukan pada tahun-tahun yang akan datang. Sedangkan untuk penanggung jawab atau pelaksana dari program-program dalam menanggulangi permasalahan air bersih mayoritas adalah PDAM Kota Surakarta yang memang berperan dalam penyediaan air perkotaan, kemudian ada pula DPU Kota Surakarta Bidang Cipta Karya juga menjadi penanggung jawab ataupun pelaksana dalam program sosialisasi mengenai pengelolaan dan pemeliharaan sumur dalam serta dalam penyediaan air bersih untuk masyarakat yang tidak berlangganan PDAM. DPU Kota Surakarta Bidang Cipta Karya bertugas memberikan penyuluhan pada Kelompok Swadaya Masyarakat (KSM) yang mengelola sumur dalam agar terjaga dari segi kuantitas, kualitas, maupun kontinuitasnya dapat memenuhi kebutuhan air masyarakat yang tidak berlangganan PDAM.

\section{b) Program Pengelolaan dalam Mengatasi Banjir}

Berdasarkan studi literature yang telah diperoleh dapat diketahui telah terdapat programprogram untuk mengatasi permasalahan resiko banjir dan genangan. Kemudian dapat diketahui juga untuk waktu pelaksanaan program tersebut adalah dari tahun 2015 hingga sekarang masih berjalan bahkan ada beberapa program yang dilaksanakan hingga pada tahun 2021. Sedangkan untuk instansi pelasanaan program-program tersebut adalah Dinas PU, BBWS, dan juga BPBD Kota Surakarta. Untuk dinas DPU sebagai instansi pelaksanaan program mengenai masalah drainase perkotaan atau drainase sekunder yang menyebabkan genangan, lalu untuk BBWS sebagai instansi pelaksana program mengenai masalah drainase primer (sungai) yang menyebabkan terjadinya banjir, sedangkan untuk BPBD sebagai instansi pelaksana untuk program tentang kesiapsiagaan dalam menghadapi bencana. Sehingga diperlukan kerjasama dan koordinasi masing-masing instansi dalam pelaksanaan program untuk mengatasi masalah banjir dan genangan yang ada di Kota Surakarta.

\section{c) Program Pengelolaan dalam Mengatasi Pencemaran Air}

Berdasarkan studi literature yang telah diperoleh dapat diketahui bahwa terdapat banyak instansi yang bertanggung jawab menjadi pelaksana dalam program-program tersebut, yaitu Bappeda, DLH, PDAM, dan juga Dinas PU sehingga diperlukan kerjasama dan koordinasi antar instansi-instansi terkait. Selain itu diperlukan juga dukungan dari pihak-pihak swasta dalam keberhasilan dari program-program tersebut. Kemudian berdasarkan tabel di atas juga dapat diketahui bahwa terdapat program yang telah dilaksanakan pada tahun-tahun sebelumnya serta terdapat beberapa program yang sekarang masih berjalan ataupun program yang akan dilaksanakan pada tahun yang akan datang. Kemudian berdasarkan program-program tersebut lebih menekankan pada pengolahan limbah, ini dikarenakan tabel di atas dapat dilihat bahwa program-program yang disusun lebih berfokus mengenai pengolahan limbah, dikarenakan masalah terbesar mengenai pencemaran air di Kota Surakarta disebabkan oleh pembuangan limbah industri khususnya industri kecil dan menengah ke sungai tanpa melalui pengolahan terlebih dahulu.

\section{d) Program Pengelolaan dalam Mengatasi Perubahan Iklim}

Berdasarkan studi literatur yang telah diperoleh dapat diketahui dapat diketahui untuk program yang telah dilaksanakan oleh pemerintah Kota Surakarta dalam hal mengatasi permasalahan perubahan iklim adalah dengan diadakannya pembangunan kampung iklim yang merupakan tanggung jawab dari DLH. Program ini telah berjalan dari tahun 2012 hingga sekarang. Dalam program pembangunan kampung iklim di Kota Surakarta diperlukan dukungan dan pastisipasi 
masyarakat agar program ini dapat berjalan sesuai dengan yang diharapkan. Masyarakat diminta aktif agar permasalahan-permasalahan lingkungan dapat diselesaikan.

Analisis Kesesuaian Program Pengelolaan dalam Mengatasi Permasalahan Air Perkotaan

\section{a)}

Analisis Kesesuaian
Pengelolaan dalam
Kelangkaan Air

Program Mengatasi

Berdasarkan analisis triangulasi sumber data dengan melihat permasalahan kelangkaan air, program pengelolaan maupun lesson learned dari pelaksanaan program, serta dari prinsip IWRM yang telah dilakukan dapat diketahui bahwa mayoritas program-program pengelolaan air perkotaan yang dilakukan telah sesuai dalam mengatasi permasalahan kelangkaan air di Kota Surakarta. Tetapi belum semua program yang dilakukan sesuai dan masalah dapat teratasi, yaitu mengenai masalah pipa jaringan jaringan PDAM yang kondisinya sudah tidak layak. Permasalahan ini belum dapat teratasi dikarenakan belum ada program yang dibuat untuk mengatasi masalah tersebut, selain itu masalah dana atau anggaran yang besar menjadi penyebab belum adanya program untuk mengatasi masalah tersebut.

Dalam mengatasi permasalahan kebocoran air ditemukan kendala pada pelaksanaan programnya karena hal pendanaan, karena untuk saat ini masih dalam tahap mencari investor dalam pengadaan alat pendeteksi kebocoran. Kemudian terkait masalah tidak adanya sumber air lain untuk saat ini masih dalam tahap pembangunan. Program ini merupakan solusi untuk mengatasi permasalahan terkait air dari Sungai Bengawan Solo yang belum bisa dikonsumsi dikarenakan kualitas airnya masih buruk dan dalam peningkatan kualitasnya membutuhkan biaya yang besar. Selain itu kerjasama tingkat kewilayahan juga telah dilakukan untuk mendukung program kegiatan tersebut.

Program-program yang dibuat dan dilaksanakan merupakan program yang berkelanjutan dan program-program tersebut dilaksanakan secara bertahap dan terus menerus. Pelaksanaan program pengelolaan untuk mengatasi masalah kelangkaan air yang ada di Kota Surakarta adalah program yang dilakukan secara menyeluruh, tidak hanya terkait penyediaan air tetapi juga dalam pengelolaannya. Selain itu program yang dilakukan telah menjangkau ke seluruh kawasan di Kota Surakarta. Sehingga air bersih dapat terdistribusi kepada seluruh masyarakat. Peningkatan kualitas air juga telah dilakukan yaitu dengan adanya sosialiasi pada masyarakat yang menggunakan sumur dalam dalam pengelolaannya agar air yang dihasilkan kualitasnya terjaga.

Pengecekan ataupun monitoring serta pembinaan juga telah dilakukan khususnya pada KSM sumur dalam untuk meningkatkan kualitas air bersih di Kota Surakarta sehingga layak untuk digunakan. Sedangkan untuk peningkatan kualitas air permukaan yaitu air Sungai Bengawan Solo untuk saat ini masih dalam tahap pengembangan, dikarenakan dalam pelaksanaanya membutuhkan biaya yang besar. Kemudian dalam hal pemanfaatan air dapat dikatakan masih kurang dikarenakan untuk sumber air yaitu Sungai Bengawan Solo untuk saat ini masih tidak layak untuk digunakan atau dikonsumsi. Sehingga pada saat ini dilakukan kerjasama regional untuk mengembangkan alternatif lain yaiu dengan mengambil dari sumber air Waduk Gajah Mungkur.

Telah adanya kerjasama yaitu dengan interaksi dan koordinasi dengan masyarakat, interaksi ini berupa dalam kegiatan sosialisasi maupun diskusi yang dihadiri oleh masyarakat. Sedangkan untuk kerjasama dengan pihak lain dapat dikatakan masih kurang, ini dikarenakan untuk masalah kelangkaan air di Kota Surakarta ditangani oleh PDAM dan juga Dinas PU. Diperlukan kerjasama dari pemerintah dan dinasdinas terkait serta khususnya dengan pihak swasta dalam hal pendanaan. Kerjasama ini sesuai dengan salah satu prinsip dari IWRM (Integrated Water Resources Management) yaitu pemerintah harus memfasilitasi dan mengadakan pengembangan sumber daya air berkelanjutan (UNDP, 2006).

\section{b) Analisis Kesesuaian Program Pengelolaan dalam Mengatasi Banjir}

Berdasarkan analisis triangulasi sumber data dengan melihat permasalahan banjir, program pengelolaan maupun lesson learned dari pelaksanaan program, serta dari prinsip IWRM yang telah dilakukan dapat diketahui bahwa program pengelolaan air perkotaan yang dilaksanakan telah sesuai untuk mengatasi permasalahan banjir di Kota Surakarta. Ini dibuktikan dengan progress kegiatan yang berjalan hingga saat ini dan dalam tahap pengerjaan, baik mulai dari pembangunan, pengerukan, normalisasi, hingga sosialiasi. Sedikit demi sedikit program yang dilakukan telah mampu untuk mengurangi banjir maupun genangan yang ada di Kota Surakarta 
Program yang dilakukan mayoritas merupakan program fisik seperti perbaikan drainase, pembangunan tanggul, normalisasi sungai, dan sebagainya. Sedangkan untuk program-program nonfisik seperti kegiatan sosialisasi secara rutin pada masyarakat terkait pentingnya menjaga lingkungan agar tidak membuang sampah di sungai.

Selain itu telah adanya monitoring dan evaluasi dalam pelaksanaan program. Untuk mengatasi permasalahan banjir maupun genangan yang ada di Kota Surakarta tidak bisa dilakukan oleh satu pihak saja, dibutuhkan kerjasama dan keterlibatan semua pihak-pihak terkait agar masalah-masalah tersebut dapat teratasi. Hal ini dikarenakan pengelolaan sumber daya air harus dikelola pada tingkat yang paling rendah (UNDP, 2006), yang masyarakat juga harus ikut menjaga dan terlibat dalam pelaksanan program.

Selain itu, dapat dilihat juga telah terjadi kerjasama ataupun kolaborasi dari dinas-dinas terkait seperti kolaborasi antara Dinas PU dengan Dinas Perumahan dan Permukiman dalam mengatasi masalah penutupan dan pendirian bangunan di atas drainase. Kolaborasi dilakukan dalam program normalisasi pada bantaran sungai dengan solusi pendirian rumah susun maupun relokasi. Ini telah sesuai dengan salah satu prinsip dari pengelolaan sumber daya air terpadu yaitu menurut Wong et al, (1999) dalam Norken (2003) yaitu melaksanakan kordinasi antar sektor dan tingkatan dalam pemerintahan.

\section{c)

Analisis Kesesuaian
Pengelolaan dalam
Pencemaran Air

Program Mengatasi

Berdasarkan analisis triangulasi sumber data dengan melihat permasalahan pencemaran air, program pengelolaan maupun lesson learned dari pelaksanaan program, serta dari prinsip IWRM yang telah dilakukan dapat diketahui bahwa telah sesuai dalam mengatasi permasalahan pencemaran air di Kota Surakarta. Ini dibuktikan dengan telah adanya program kegiatan yang dilakukan untuk mengatasi masing-masing permasalahan pencemaran air yang ada di Kota Surakarta.

Untuk permasalahan terkait rendahnya pemasangan pipa, IPLT yang tidak berfungsi, dan minimnya pendanaan APBD masih ditemukan kendala dalam pelaksanaan programnya. Hal ini dikarenakan untuk saat ini masih terkendala dalam hal pendanaan dan masih belum adanya kerjasama terutama dengan pihak swasta.

Program yang dilakukan untuk mengatasi masalah pencemaran air merupakan program yang dilaksanakan secara bertahap dan berkelanjutan dan melibatkan berbagai stakeholder. Kebijakan atau program yang dibuat juga berfokus pada pengelolaannya. Selain itu, telah ada kebijakan maupun peraturan yang dibuat untuk mengatasi masalah pencemaran air di Kota Surakarta. Ini bertujuan untuk memberikan sanksi atau efek jera bagi para pelanggar atau kontributor limbah cair agar tidak membuang limbah di sungai. Pemberian sanksi ini mulai dari pengawasan dan pembinaan untuk yang melakukan pelanggaran ringan hingga tindakan pidana untuk kontributor limbah cair yang dianggap melakukan pelanggaran berat. Ini sesuai dengan prinsip pengelolaan sumberdaya air terpadu menurut UNDP (2006) yaitu pemerintah harus mendukung pengembangan sumber daya air yang berkelanjutan yang didukung dengan kebijakan maupun peraturan

Dalam hal pemanfaatan air bekas olahan masih dapat dikatakan belum ada pemanfaatan, hal ini dikarenakan untuk air hasil olahan masih belum bisa dimanfaatkan kembali. Sehingga untuk saat ini air dari hasil olahan langsung dibuang ke sungai. Sedangkan untuk meningkatkan kualitas air sungai telah dilakukan studi terkait daya dukung dan daya tampung sungai untuk mengetahui kadar pencemaran air sungai yang ada di Kota Surakarta.

Telah ada koordinasi dan kerjasama dengan beberapa pihak terkait tugasnya masing-masing seperti DLH, Bappeda, PDAM, DPU. Partisipasi masyarakat juga dapat dikatakan tinggi, karena masyarakat aktif dalam mengikuti sosialisasi yang diadakan serta ikut terjun langsung dalam pelaksanaan programnya. Ini sesuai dengan salah satu prinsip pengelolaan sumber daya terpadu, yaitu pengelolaan sumber daya air harus dilakukan pada tingkat paling rendah yaitu masyarakat yang juga harus ikut membantu untuk mendukung program kegiatan terlaksana dengan baik. Ini dibuktikan dengan adanya kerjasama dan koordinasi antar masing-masing stakeholder baik oleh pemerintah, swasta, maupun masyarakat. Ini sesuai dengan prinsip pengelolaan sumber daya air terpadu yang menurut Wong et al (1999) dalam Norken (2003) menyatakan salah satu prinsip dalam pengelolaan sumber daya air terpadu (Integrated Water Resources Management) yaitu dengan mengikutsertakan seluruh stakeholder dalam pengambilan keputusan pengelolaan sumber daya air serta melaksanakan kordinasi antarsektor dan tingkatan dalam pemerintahan. Dalam hal ini seluruh stakeholder, baik pemerintah, swasta, maupun masyarakat ikut serta dalam pengelolaan sumber daya air perkotaan. 


\section{d)

Analisis Kesesuaian
Pengelolaan dalam
Perubahan Iklim

Berdasarkan analisis triangulasi sumber data dengan melihat permasalahan perubahan iklim, program pengelolaan, maupun lesson learned dari pelaksanaan program, serta dari prinsip IWRM dapat diketahui bahwa program pengelolaan yang dilakukan telah sesuai dalam mengatasi masalah perubahan iklim. Ini dibuktikan dengan semakin gencarnya pemerintah melakukan sosialisasi tentang program kampung iklim yang akan berdampak pada lingkungan sekitar dan juga air perkotaan di Kota Surakarta. Tetapi untuk untuk pelaksanaan program kegiatan yang dilakukan masih terbatas pada beberapa kelurahan yang ada di Kota Surakarta sehingga masih belum memiliki dampak yang besar. Untuk saat ini sosialiasi pada masyarakat terus dilakukan. Program ini diharapkan dapat diterapkan pada seluruh kelurahan yang ada di Kota Surakarta dan dilakukan secara bertahap dari tahun ke tahun. Kebijakan atau program yang dilakukan sedikit demi sedikit telah mampu untuk mengatasi masalah tersebut.

Masyarakat dituntut untuk ikut serta dalam pelaksanaan kegiatan program tersebut. Hal ini dapat dilihat dengan tingginya minat masyarakat dalam pelaksanaan program kampung iklim. Pada kegiatan ini masyarakat dan juga dinas terkait saling berinteraksi. Semua pihak yang terlibat saling berdiskusi untuk menemukan solusi-solusi dalam mengatasi masalah-masalah perubahan iklim. Ini sesuai dengan yang dikatakan oleh Gray (1989) yang menggambarkan bahwa kolaborasi sebagai suatu proses berpikir pada pihak yang terlibat memandang aspek-aspek perbedaan dari suatu masalah serta menemukan solusi dari perbedaan tersebut dan keterbatasan pandangan mereka terhadap apa yang dapat dilakukan. Kerjasama dalam program ini masih sebatas antara DLH dan juga masyarakat, belum adanya swasta yang ikut terlibat langsung dalam pelaksanaan program ini. Sosialisasi yang dilakukan merupakan interaksi yaitu pengenalan dengan masyarakat terkait program kampung iklim. Masyarakat dituntut untuk ikut serta dalam pelaksanaan kegiatan program.

\section{SIMPULAN}

Berdasarkan analisis yang telah dilakukan dengan menggunakan analisis triangulasi sumber data dapat disimpulkan bahwa telah terjadi kesesuaian program pengelolaan dalam mengatasi permasalahan air perkotaan yang ada di Kota
Surakarta. Tetapi tidak semua program pengelolaan sesuai dalam mengatasi permasalahan air perkotaan di Kota Surakarta. Terdapat permasalahan air perkotaan yang saat ini masih belum teratasi karena masih belum adanya program pengelolaan yang sesuai, yaitu mengenai hal kelangkaan air terkait masalah pipa jaringan PDAM kondisinya sudah tidak layak. Hal ini dikarenakan masih belum adanya program yang dibuat untuk mengatasi masalah tersebut. Selain itu terdapat pula permasalahan air perkotaan yang terkendala dalam hal pendanaan, antara lain mengenai masalah kebocoran air, tidak adanya sumber air lain, IPLT yang tidak berfungsi, rendahnya pemasangan pipa atau saluran air limbah minimnya pendanaan APBD, serta terkait masalah terjadinya kerusakan lingkungan. Sehingga untuk saat ini masih dalam tahap sosialisasi maupun pembangunan.

Beberapa program membutuhkan biaya yang tidak sedikit. Keterlibatan pihak swasta dalam hal pendanaan dirasa masih kurang. Sehingga perlu ditingkatkan lagi kerjasama khususnya dengan pihak swasta terkait hal ini. Kerjasama dengan instansi lain dirasa sudah cukup baik karena telah ada koordinasi antar pihak. Selain itu kerjasama juga telah dilakukan dengan KSM terkait pengelolaan sarana prasarana maupun masyarakat dengan diadakannya kegiatan sosialiasi atau pendekatan pada masyarakat.

Program yang dilakukan merupakan program fisik seperti pembangunan dan perbaikan maupun program nonfisik seperti sosialisasi dan permberdayaan masyarakat. Selain untuk mengatasi permasalahan air perkotaan, program yang dilakukan juga berfokus dalam hal pengelolaannya, yaitu menyeluruh dan berkelanjutan yang dilakukan secara bertahap. Sedangkan dalam hal pemerataan,air untuk program yang dilakukan saat ini sudah merata dan dilaksanakan pada seluruh kawasan di Kota Surakart. Selain itu, telah terdapat penelitian terkait studi daya dukung dan daya tampung air sungai untuk memantau kualitas dari air sungai yang ada di Kota Surakarta. Untuk pemanfaatan air, masih ditemukan kendala karena sampai saat ini air limbah hasil olahan maupun air dari Sungai Bengawan Solo masih belum bisa dimanfaatkan dan dikonsumsi.

Berdasarkan hal tersebut kesesuaian pengelolaan air perkotaan untuk mengatasi masalah air perkotaan di Kota Surakarta telah mengarah pada implementasi teori pengelolaan sumber daya air terpadu (Integrated Water Resource Management), karena program-program pengelolaannya telah berupaya untuk melibatkan seluruh stakeholder-stakeholder terkait. 


\section{UCAPAN TERIMA KASIH}

Terima kasih kepada Prodi Perencanaan Wilayah dan Kota Fakultas Teknik Universitas Sebelas Maret yang telah memberikan ijin kepada penulis untuk melaksanakan penelitian.

\section{DAFTAR PUSTAKA}

Abdollahi, Sima. 2014. Stakeholder Relations and Public Participation in Peri-Urban Water and Sanitary Management. Gothenburg, Sweden. Chalmers University of Technology.

Bappenas. 2011. Ironi Air di Indonesia, Menyingkap Potensi Perang Air, Belajar tentang Air dari Swedia. Sustaining Partnership.

Bryson, John .M., 2003. What to Do When Stakeholders Matters: A Guide to Stakeholders Identification and Techniques". A paper presented at the National Public Management Research Conference. Goergetown University Public Policy Institute, Washington, D.C.

Helness H, Damman S, de Clercq WP, Elema NM. 2017. A Framework for Integrated Sustainability Assessment of Water Cycle Services. European Journal of Sustainable Development.

Samidjo, Jacobus. Pengelolaan Sumber Daya Air. PAWIYATAN, [S.1.], v. 21, n. 1, apr. 2014. Available at:

http://ejournal.ikipveteran.ac.id/index.php/ pawiyatan/article/view/7. Date accessed: 09 nov. 2018.

Masterplan Air Limbah Kota Surakarta Tahun 2016

Mollinga, P.P,. 2008. Framing a Political Sociology of Water Resources Management. Water Alternatives 1(1): 723.

Muzani, 2014. Strategi Peningkatan Peran Stakeholder dalam Pengelolaan Mangrove di Kabupaten Tangerang. Spatial Wahana Komunikasi dan Informasi Geografi Vol.12 No.2 September 2014.

Penyusunan Rencana Program Investasi Jangka Menengah (RPIJM) Bidang Cipta Karya Kota Surakarta 2018-2022

PP No.121 Tahun 2015 tentang Pengusahaan Sumber Daya Air.
Reed, MS. 2009. Who Is In and Why? A Typology of Stakeholder Analysis Methods for Natural Resource Management. Journal of Environmental Management.

Rencana Induk Sistem Penyediaan Air Minum (RISPAM) Kota Surakarta Tahun 2016

Rencana Kerja Pemerintahan Daerah Kota Surakarta Tahun 2017

Rencana Pembangunan Jangka Menengah Daerah (RPJMD) Kota Surakarta Tahun 2016-2021

Rencana Tata Ruang dan Wilayah (RTRW) Kota Surakarta Tahun 2011-2031

Rogers, Peter and Hall, Alan W. 2003. Effective Water Governance. Elanders Novum, Sweden.

Suharsimi, Arikunto. 2008. Evaluasi program pendidikan. Jakarta. PT. Bumi Aksara.

TI (Transparency International). 2008. Global corruption report 2008 - Corruption in the water sector. Washington, DC: TI. Cambridge, UK: Cambridge University Press.

UCCRN. 2011. Urban Climate Change Research Network: Climate Change and Cities. First Assessment Report of the Urban Climate Change Research Network. Cambridge University Press.

UNDP. 2006. Mainstreaming Gender in Water Management. [Online] http://www.undp.org/content/undp/en/hom e/librarypage/environmentenergy/water_go vernance/resource-guide-mainstreaminggender-in-watermanagement.html. Diakses pada Selasa, 3 Oktober 2017 pukul 20.41.

Van Leeuwen, CJ, and Chandy, P. C. 2013. The City Blueprint: Experiences with the Implementation of 24 Indicators to Assess the Sustainability of the Urban Water Cycle. Water Science and Technology. Water Supply, 13(3), 769-781.

Van Leeuwen CJ, Frijns J, Van Wezel A, Van De Ven, FHM. 2012. City Blueprints: 24 Indicators to Assess the Sustainability of the Urban Water Cycle. Springer Science Business Media B.V.

Van Leeuwen CJ, Koop SHA, Sjerps RMA. 2015). City Blueprints: Baseline Assessments of Water Management and Climate Change in 45 Cities. Environ Dev Sustain, 18:1113-112.

Wirawan. 2012. Evaluasi Kinerja Sumberdaya Manusia. Jakarta. PT. Salembat Empat. 